〔12〕アクリロニトリルとアリルスルホン酸ソーダの共重合 (1963 年 8 月 1 日受理)

宮道一夫*・鈴木 亮* 原田 享*・片山将道*

\footnotetext{
要旨次の二つの系についてアクリロニトリル (AN) とアリルスルホン酸ソーダ (SAS) の共重合を 行ない, SAS の仕込み組成 50 モル\% 以下の箅曲で共重合反応性比 (MRR) を求めた。

溶液重合 (溶鼡: ジメチルスルホキシド, 開始剤: アジビスイソブチロニトリル，重合温度 : $60^{\circ} \mathrm{C}$ ) $r_{1}(\mathrm{AN})=0.69 \pm 0.05, \quad r_{2}(\mathrm{SAS})=0.18 \pm 0.05$

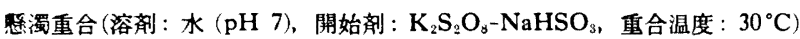
$r_{1}(\mathrm{AN})=4.94 \pm 0.06, \quad r_{2}(\mathrm{SAS})=0.07 \pm 0.06$

なお, 溶液重合で求められた MRR および AN に対する $Q(=0.44)$ および $e(=1.2)$ 值から SAS に対 する $Q$ および $e$ 值を計算したところ, それぞれ 0.11 および -0.24 であったこれらの結果は, 主として, モノマーのエチレン二重結合の極性効果に基いて検即された。
}

\section{1. 緒言}

SAS はアクリロニトリル采合成繊維にカチオン染料 に対する親和性を与えるとともに水采湿式紡采における 失透現象を防ぐ共重合成分として有用であるが1)，AN と SAS の MRR を求めた例は知られていない。

本報告では，アゾビスイソブチロニトリル (AIBN) を 開始剤としジメチルスルホキシド (DMSO) を溶用とす る均一系溶液重台および, $\mathrm{K}_{2} \mathrm{~S}_{2} \mathrm{O}_{8}-\mathrm{NaHSO}_{3}$ を開始郕と し水を溶郕とする不均一采恶濁重合の二つの系について AN と SAS の MRR を求め, それらの共重合挙動に ついて考察を加える。前者の重合系はわれわれがアクリ ロニトリル采㵶維の半工業的生産に用いているものであ り, 後者の重合系は一般に用いられているものである。 なお，溶液重合では SAS の仕込み組成 60 モル％以 上になると共重合体の分離が困難であったので，本実験 では MRR の決定は両重合系とも50 モル\%以下で行 なった。

\section{2. 実験}

\section{1 物質の精製}

$\mathrm{AN}$ は希カ七イソーダ水溶液, 希硫酸水溶苳および水 で逐次洗浄し，塩化カルシウム上で乾燥したのち窒素下 で 2 回蒸留した。SAS は $10 \%$ 含水ェタノール, AIBN はエーテル, 過硫酸カリウムは水をそれぞれ溶剂として, 再結晶を 2 回繰り返すことにより精製した。亜硫酸水素 ナトリウムは市販特級試薬をそのまま用いた。DMSOは 水酸化カリウム上で脱水した後, 空素下で減圧蒸留を 2 回行なった。水は蒸留水を用い, 重合直前窒素を吹き込

* 日東紡維株式会社化裁研究所 (福岛県安積郡富久山町)
むことにより溶存空気を除去した。

\section{2 共重合}

溶液重合は硬質ガラス管中 (封管)また照濁重合は三つ ロフラスコ中 (かきまぜ速度 200 r.p.m.) で行なった。い ずれもふんい気は窒素で置換した。重合条件は Table 1 に付記される。後者の溶剤として用いた水は微量のカ七 イソーダを加えることにより $\mathrm{pH} 7$ に調節した。

生成物は大量のメタノール中に沈殿させ, さらにメタ ノールで数回洗浄したのち，減圧下で乾燥した。なお， 溶液重合では SAS 仕込み組成 60 モル \% 以上では 7 時間以上重合しても重合体を分離できなかった。これは 3.2 に示す結果から予測されるように，この組成笅囲で は高 SAS 含量のオリゴマーが生成し（重合したとして も),このものの溶解性は SAS のそれとほとんど変わ らないことによるものであろう。このような理由から MRR の決定は SAS の仕込み組成 50 モル\% 以下で 行なうことにする。

また, 共重合体, 特に溶液重合で得られた高 SAS 含量 のものは SAS と溶解性が類似しているために未抽出の SAS を含む可能性がある。全試料について赤外吸収ス ペクトルにより二重結合の存在を調べたところ、いずれ も二重結合に基く吸収は現われなかったので，共重合体 とモノマーの分離は良好に行なわれたとみなしてよい。

\section{3 共重合体組成の決定}

共重合体組成の決定には空素分析(ケールダール法) お よびイオウ分析 ${ }^{2}$ の両者を併用した。両者の方法によっ て求めた組成值は, 一部の試料を除き $1.5 \%$ 以下の誤差 䈥囲で一致した。

\section{4 希薄溶液粘度の测定}

希薄溶液粘度の測定には希釈型ウベロード粘度管を用 いた。 
Table 1. Copolymerization of AN and SAS*.

\begin{tabular}{|c|c|c|c|c|}
\hline \multirow{2}{*}{$\begin{array}{l}\text { SAS in the } \\
\text { monomer feed } \\
(\mathrm{mol} \%)\end{array}$} & \multirow{2}{*}{$\begin{array}{l}\text { Conversion } \\
\quad(w t \%)\end{array}$} & \multirow{2}{*}{$\begin{array}{l}\text { Time of the runs } \\
\text { (min) }\end{array}$} & \multicolumn{2}{|c|}{ SAS in the copolymer $(\mathrm{mol} \%)$} \\
\hline & & & From nitrogen content & From sulfur content \\
\hline \multicolumn{5}{|c|}{ Solution polymerization } \\
\hline 10 & 10.1 & 50 & 14.0 & 12.8 \\
\hline 20 & 10.9 & 60 & 19.3 & 20.6 \\
\hline 25 & 11.2 & 80 & 27.1 & 27.4 \\
\hline 35 & 13.2 & 140 & 32.1 & 27.6 \\
\hline 50 & 12.2 & 300 & 39.0 & 39.4 \\
\hline \multicolumn{5}{|c|}{ Suspension polymerization } \\
\hline 10 & 3.45 & 20 & 2.2 & 3.6 \\
\hline 20 & 4.58 & 25 & 2.9 & 5.0 \\
\hline 30 & 2.96 & 35 & 9.7 & 10.2 \\
\hline 40 & 2.38 & 60 & 10.2 & 12.3 \\
\hline 50 & 2.51 & 100 & 13.3 & 15.0 \\
\hline
\end{tabular}

* Copolymerization conditions: Monomer $3.0 \mathrm{~mol} / l$, Azobisisobutyronitrile $1 \times 10^{-2} \mathrm{~mol} / l$, at $60^{\circ} \mathrm{C}$ in the solution polymerization and monomer $1.0 \mathrm{~mol} / l, \mathrm{~K}_{2} \mathrm{~S} \mathrm{O}, 3.5 \times 10^{-3} \mathrm{~mol} / l, \mathrm{NaHSO}_{3} 3.5 \times 10^{-3} \mathrm{~mol} / l$, at $30^{\circ} \mathrm{C}$ in the suspension polymerization

\section{3. 結 果}

\section{1 共重合結果および MRR}

Table 1 には各仕込み組成に扔ける重合辛，その重合 率に到達するまでに要した時間および共重合体の組成が 示される。明らかに SAS の仕込み量が増加すると重合 速度は著しく低下する。各組成值から直線交差法を用、 てMRR を求めると次の值が得られた。

溶液重合：

$$
\begin{aligned}
& r_{1}(\mathrm{AN})=0.69 \pm 0.05, \quad r_{2}(\mathrm{SAS})=0.18 \pm 0.05 \\
& \text { 照濁重合 : } \\
& r_{1}(\mathrm{AN})=4.94 \pm 0.06, \quad r_{2}(\mathrm{SAS})=0.07 \pm 0.06
\end{aligned}
$$

Fig. 1 には実験值およびこれらの $r_{1}$ および $r_{2}$ 值を 用いて計算した組成曲線が示される。

\subsection{AN-SAS 共重合体の希薄溶液粘度}

Fig. 2 および 3 に示されるように AN-SAS 共重合 体は高誘電率の溶绪 (水: 77, DMSO：45, ジメチル木 ルムアミド (DMF)：27) 中では電解質的粘度挙動を 示 す。したがって，SAS および生成共重合体(とくに溶液 重合において)のイオン解離は当然考えられてよい。ま た,このような希薄溶液粘度の電解質的挙動のために極 限粘度数 $[\eta]$ から共重合体の分子量を推定することは困 難となるが, Fig. 3 に示した AN-SAS (39 モル \%) 共 重合体の各濃度の $\mathrm{NaCl}$ 水溶液中における粘度測定の 結果から，この共重合体は低分子星のものであることが

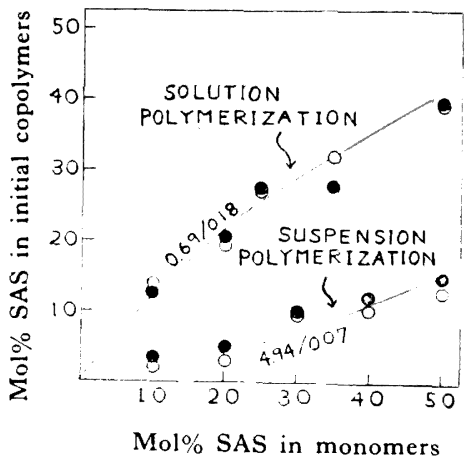

Experimental points, determined from nitrogen content (O) and sulfur content

Composition curves, calculated for the MRR values indicated $\left(r_{1} / r_{2}\right)$

Fig. 1. Monomer-copolymer composition curves for AN (1)-SAS (2).

わかる。なお，本溶液重合と同一条件で調製したポリア クリロニトリルの $[r]\left(\mathrm{DMF}\right.$ 中, $\left.30^{\circ} \mathrm{C}\right)$ は 2.6 であっ た。したがって, SAS 仕込み量の增加とともに生成共 重合体の分子量は急激に低下すると考えてよい。

\section{4. 考察}

3. で示した実験結果から，不均一系照濁重合では AN の反忘性が著しく大きいのに対し，均一系溶液重合では 


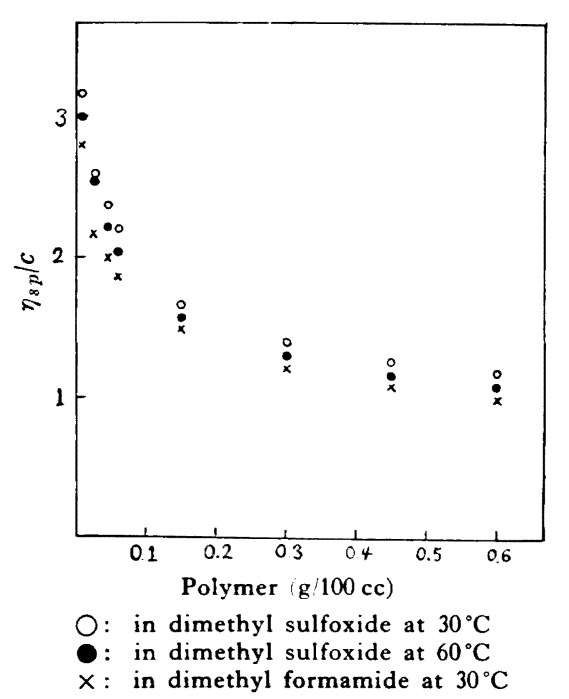

Fig. 2. $\eta_{s p} / c$ against $c$ for AN-SAS (8 mol\%) copolymer.

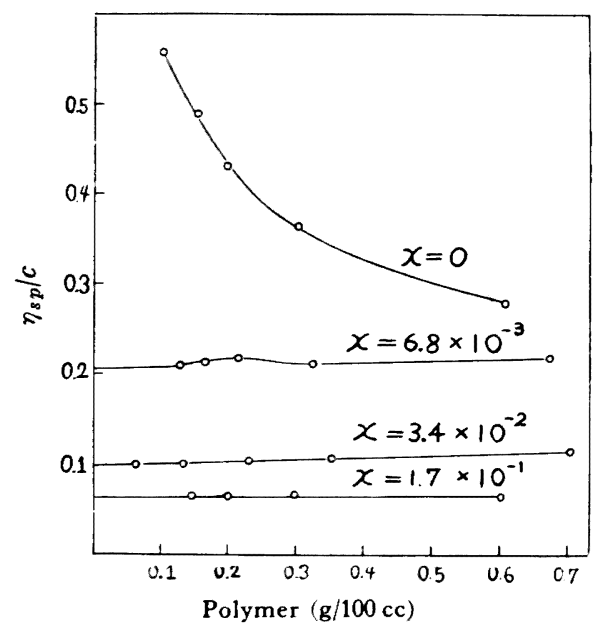

Fig. 3. $\eta_{s p} / c$ against $c$ for AN-SAS (39 mol\%) copolymer in aqueous $\mathrm{NaCl}$ solutions of various concentration $x(\mathrm{~mol} / l)$.

AN と SAS の交互性が強いことがわかる。

㦟濁重合では, AN は水に一部溶解するのみで大部分 は非溶解状態に止まるが SAS は水に完全に溶解する。 一般に AN の水系重合においては分散して存在する AN が生成重合体粒子に拡散吸着して重合が進行するこ とが認められておりる，また AN の共重合においても モノマーの反応性は重合系(均一系, 不均一系)によって 異なることが知られている゙。本孯濁重合で観測された AN の高い反応性はこのようなことを考慮すれば理解で
きると思われる。

溶液重合では両モノマーとも溶剤に完全に溶解してい るので, 懸濁重合で認められたような重合機構の複雑さ は存在しないはずである。したがって, 溶液重合のモ, マー反応性には, 主として, モノマーの性質, 特にそのエ チレン二重結合の極性が関倸するものと思われる。AN のエチレン二重結合は $\mathrm{CN}$ 基の電子吸引力のために正 に分極している。 $\mathrm{SAS}$ の場合も $\mathrm{SO}_{3}$ 基の雪子吸引力が 働くが、二重結合と $\mathrm{SO}_{3}$ 基の間に存在するメチレン基 のためにその力はほぼ半減される。また DMSO 中では $\mathrm{SO}_{3}$ 基はアニオンに解離しているので, この効果も電子 吸引力を弱めるように牛く。したがって，エチレン二重 結合上の電子密度が高いSAS と電子密度が低、AN との間にはかなりの交互性が期待されてよいはずであ $\eta$, 求为られた $r_{1} \cdot r_{2}(=0.12)$ 值はほぼ妥当なものとい える。なお，この場合立体効果も考えられるが，本重合 采では成長鎖はイオン解離のためかなり伸びた形態をと っているので (3.2 参照), イオン解離していない場合よ りも隣接基による立体障害は小さいといえるかもしれな い。

溶液重合では SAS の仕込み量が増加すると生成共重 合体の分子量は著しく低下することが認められたが，こ れは，一般にアリル化合物の重合において認められてい るように, 成長鎖末端のラジカルが SAS モノマーのメ チレン基の水素を引き抜くことにより連鎖の生長を停止 するためであろう (degradative chain transfer)。した がって，末端の SAS ラジカルはかなり不安定なものと 考えられる。

ここで溶液重合で得られた MRR 值および AN に対 する $Q(=0.44), e(=1.2)$ 值から求为た SAS に対す る $Q, e$ 值を $n$-butyl vinylsulfonate (BVS) $)^{5)}$ おょび $p$-sodium styrene sulfonate (SSS) ${ }^{6}$ に対する值ととも に Table 2 に示す*1。SAS に対する $Q, e$ 值は, 傾向と

Table 2. Price $Q$ and $c$ values for SAS and other monomers containing sulfonate group.

\begin{tabular}{c|ccc|c}
\hline Monomer & $Q$ & $e$ & $\begin{array}{c}\text { Polymerization } \\
\text { system }\end{array}$ \\
\hline $\begin{array}{c}n \text {-Butyl vinyl } \\
\text { sulfonate }\end{array}$ & 0.02 & 0.84 & Bulk \\
\hline $\begin{array}{c}p \text {-Sodium } \\
\text { styrene sulfonate }\end{array}$ & 0.76 & -0.26 & -0.46 & at pH 3 \\
\hline $\begin{array}{r}\text { Sodium allyl } \\
\text { sulfonate }\end{array}$ & 0.11 & -0.24 & Suspension \\
\hline
\end{tabular}

*1 赖濁重合から得られた MRR からは $Q=0.03, e=0.17$ と なった。ただし，その重合機構の複雑さからみて合理的な值と思 われないので Table 2 には記载しない。 
して, 前記の考察と一致し, また BVS および SSS に 対する $Q, e$ 值から推定される値に近い。

以上述べた考察からみて, 本実験がせまい組成範囲で 行なわれたにもかかわらず, 得られた結果はかなり合理 的であるといえる。

付 眍：共重合体の組成分析に協力された更科茂昭氏に感撮 します。

$$
\text { 文献 }
$$

1) 内藤万寿雄, 原田 享, 片山将道：特公昭 36-4016
2) 穂積啓一郎, 三浦英男：分析化学, 11，640(1962)

3）長尾英夫, 内田盛也, 山口晃雄：工化, 59, 695 (1956)

4) J. Brandrup: Faserforsch. u. Textiltech., 12, 133, 208(1961)

5) C. G. Overberger, D. E. Baldwin, H. P. Gregor: J. Am. Chem. Soc., 72, 4864 (1950)

6) Z. Izumi, H. Kiuchi, M. Watanabe: J. Polymer Sci., Part A, 1, 705(1963)

\title{
Copolymerization of Acrylonitrile and Sodium Allyl Sulfonate
}

\author{
By Kazuo Miyamichi*, Akira Suzuki*, Susumu Harada* and \\ Masamichi Katayama*
}

Monomer reactivity ratios (MRR) for acrylonitrile (AN)-sodium allyl sulfonate (SAS) were determined by carrying out solution polymerization (initiated with azobisisobutyronitrile at $60^{\circ} \mathrm{C}$ in dimethyl sulfoxide) and suspension polymerization (initiated with $\mathrm{K}_{2} \mathrm{~S}_{2} \mathrm{O}_{8}-\mathrm{NaHSO}_{3}$ at $30^{\circ} \mathrm{C}$ in water).

The MRR values estimated were $r_{1}(\mathrm{AN})=0.69 \pm 0.05, r_{2}$ (SAS) $=0.18 \pm 0.05$ for the solution polymerization and $r_{1}(\mathrm{AN})=4.94 \pm 0.06, r_{2}(\mathrm{SAS})=0.07 \pm 0.06$ for the suspension polymerization. From the MRR values for the solution polymerization and $Q(=0.44)$ and $e(=1.2)$ for $\mathrm{AN}$, Price $-Q$ and $-e$ values for SAS were also calculated to be 0.11 and -0.24 respectively.

The results were discussed mainly in terms of the polarity of the monomers.

* Research Laboratory for Chemical Fibers, Nitto Boseki Co. (Fukuyama-machi, Asaka-gun, Fukushima) 